\title{
Research on the Public English Flipped Classroom Teaching Modes in Higher Vocational Colleges under the Information Technology Environment
}

\author{
Bi Lihua \\ Jinan Engineering Vocational and Technical College,250200, Jinan, Shandong \\ 346591653@163.com
}

Keywords: Teaching mode; Higher vocational public English; Flipped classroom; Information technology environment

\begin{abstract}
Flipped classroom teaching mode was introduced into China since 2011, and many experts, academics, or teachers have begun to introduce and practise it. The author takes "flipped classroom" as a kind of teaching mode reform, and takes advantage of technology tools and information resources, flipping over the traditional higher vocational public English teaching structure, and lets students have a powerful self-learning control. Students watch Micro-videos before or in class, through the teaching guidance and technical tools, and the students carry on self-organization of inquiry learning, and discuss in group during class, while the teacher answers questions raised by students, and encourages collaborative learning among students. In the process of setting up a learning environment, teachers should also consider how to monitor the students' learning behavior and provide timely feedback to the students who are in trouble. In the process of classroom teaching, teachers should re-layout the traditional classroom, breaking the original pattern "teachers on the classroom stage, students below the classroom stage", creating a harmonious and equal learning environment. This mode is a great inspiration to Higher Vocational College English teaching.
\end{abstract}

\section{Introduction}

With the popularity of the open class at Stanford University, Harvard University and the rapid development of online videos of other public courses in the network, "flipped classroom" teaching extends to the basic education, which makes it possible to share the high quality education resources. Under the information technology environment, most Vocational College English teachers reach the consensus of "flipped classroom" teaching in Higher Vocational College English. So "how to flip the classroom teaching? And how to change teaching mode?" These two questions will be the focus of the study.

With the vigorous development of information technology these years and the increase of country investment, the construction of information technology environment in higher vocational colleges has a good foundation. Especially in the construction of campus network and the wireless network, with the advantage of its flexibility, high bandwidth and wireless access, many people are on the Internet at the same time. The campus network facilitates the teachers and students to obtain information conveniently and further enhance the school's informatization level. In addition, the introduction of the wireless network environment provides an application platform with the new wireless multimedia, which will bring the construction of educational information into a new world. Therefore, "how to use the campus network to carry on the flipped classroom teaching?" This will be the focus of further research.

\section{Current research situation at home and abroad}

Current research situation abroad. The "flipped classroom" teaching is to change the traditional class teaching methods, in which the teacher teaches in class, and the students complete homework after class. In the "flipped classroom” teaching, the students watch micro-videos before class; carry on collaborative learning and practice learning activities in class. 
The "flipped classroom" teaching began in the United States and in the view of the recent development of it in the United States, it is mainly used in mathematics, physics, chemistry and science, and the distinct features of these subjects is they all have a clear definition. The micro-videos introduce and explain the concept, and students can acquire knowledge through the micro-videos. In the practical subjects, teachers can explain the operation steps through micro-videos, and what should be paid attention to in each step, while through extracurricular learning, students can do practical exercises in class. For the study of language subjects, teachers can explain the language rules through micro-videos, and there is more time for the exchange of language between teachers and students in the classroom.

Current research situation at home . In China, there are a preliminary study and development of the flipped classroom. In practice, Chongqing Jukui secondary school walks in the the forefront of the country, and becomes the practice paradigm in the field of flipped classroom teaching. In the flip classroom teaching in Jukui school, teachers make the guiding case, create the teaching video, and then upload the learning resources to the campus "cloud" service platform; while the students download teaching videos and guiding case via their own tablet computers before class and start learning; students can complete the self-testing preview questions through computer network platform, and solve problems in groups through mutual assistance. If there are some problems that cannot be solved in groups, the group leader should hand over these problems to the course representative, and the course representative upload them to the server. On the basis of these problems, the teacher has a better understanding of students' pre learning and learning situation, so the teacher can adjust the teaching schedule and make detailed teaching plan. In this process, the traditional cramming method of teaching mode is completely "flipped", and transforming from "teacher-oriented teaching-students' passive learning" to "students-oriented learning - problems finding- teachers guidance to solve the problem". Moreover, there are many teachers and enterprise training personnel also practise the flipped classroom concept, but most research results are the introduction of foreign study and thinking of the theory localization, and there is little specific implementation, so it is important to practise the flipped classroom by the front-line practitioners, and then build a localization pattern.

\section{The design for public English flipped classroom teaching modes in higher vocational colleges under the information technology environment can be divided into four parts}

The teacher makes micro-videos before class, and students watch videos and learn by themselves. The teacher design a task list, providing micro-videos and learning resources to help students clarify the aim of the studying, objectives, methods and learning test before class. The micro-videos are about 10 minutes, and the teacher should pay attention to the key words, sentence patterns and English grammar in the 10 minutes. The language context and language sense are very important, so in the course of making micro-videos, it is necessary to add some animations, video, audio, pictures and other related materials to the content. Through watching these teaching materials, students can cultivate the sense of language, improve the level of listening, and finally achieve the learning goal.

After watching videos, students can interact with the teacher or other students about their harvest and doubt through the QQ group and other online communication tools. At the same time, the students should also complete the teacher's assignment in the exercises, in order to deepen the understanding of the content.

The establishment of website in accordance with flipped classroom, supplying supplementary English current material for students to learn and refer to in and out of class. With the development of current society, the requirements of students to learn are not limited to traditional textbooks and classroom teaching. The lagging materials in the textbook can not meet the requirements of students to keep track of current affairs, which requires teachers to search current materials for students to study, so as to help students become familiar with the English language and learn more about western cultural context. Due to the highest attention to the domestic and foreign affairs, college students listen to professional reviews and reports based on a little understanding of 
the event, which can not only understand the press releases, but also can better understand the hidden social, historical and cultural background. It is beneficial for the students to further study the language and enhance the students ability in communicating in English.

Therefore, at the moment, the more practical approach is to establish the website adapted to flipped classroom, and supply supplementary information on current events for students to learn and refer to in and out of class.

The teacher organizes classroom activities, guiding students to exchange ideas and interact with each other, in order to solve the problem. After the teaching content is transferred to the students outside class, then the in-class needs a high quality of learning activities, and the students have the opportunity to apply what have learned to specific environment. These activities include: creating content, independent problem solving, inquiry activities and project based learning.

As the teacher's role has changed from the content presenter to the coach of learning, which allows teachers to have time to talk with students and answer questions from students. In the process of answering students' question, we will notice some of the students have the same problem, and

this part of the students will be divided into a group, which requires the teacher to participate in the study group, and give guidance in a timely manner.

In the classroom, teachers should also guide the students to communicate with each other after the students' self-learning and interactive communication, and give feedback to each other between the teachers and students. English teaching should pay attention to the improvement of students' ability of listening, speaking, reading and writing, so the teacher in the classroom should make full use of the cooperation between the students, let students practice English should be learned, and deepen the understanding of words, sentences and grammar.

The teacher should pay attention to the application of information technology. The successful implementation of the flipped classroom can not be separated from the advanced information technology, such as multimedia technology, network technology and so on. In the teaching of flipped classroom, the modern information technology, such as audio and video recording, editing and network communication are essential. In the implementation of the flipped classroom,the teachers should master modern information technology, and have the ability to make teaching videos and electronic courseware, as well as the ability to use the network platform for visualization of teaching. Therefore, teachers should have a profound understanding of the necessity and urgency of the important status of modern information technology in the flipped classroom and its application, through a variety of training and learning, and try hard to grasp and apply the modern information technology, improving their own ability to meet the needs of the flipped classroom teaching.

\section{The specific measures for implementation}

Since the beginning of September 2015, with the combination of "College English" course standard, the author carried on the experiment of " flipped classroom " teaching mode in the class of Engineering Cost 1501-06, the class of Construction Engineering Technology 1501 (undergraduate).The experimental result is good. The students watch the micro-videos online before class, and learn the English text in groups by themselves. In class, the students read, translate and explain the text in groups in order to improve the students' English learning interests and self-studying ability. In the future, the English " flipped classroom " teaching mode will extend to the whole college.

Take advantage of English website, Duigoo Micro-video Website, English Wechat public accounts and Moso Teach1, and let the students develop the habit of learning English anytime and anywhere. (1)Takes full consideration of the characteristics of higher vocational students who like to watch videos through the network and mobile phone, and the author takes advantage of modern information technology, so that the students will learn English anytime and anywhere. Some English Wechat public accounts are as follows: Daily English(daily- english), 21st Century(i21stCentury), Keke English(ikekenet).

\footnotetext{
${ }^{1}$ Moso Teach is a kind of mobile phone App in which the teacher can create online classes and post materials.
} 
(2) The author monitors students' learning effect and adjusts the teaching content through the background data management platform of Moso Teach and Duigoo Micro-video Website. By the end of January 2016, the author posts 149 online micro-videos at Duigoo Micro-video Website, the total number of students is 167, the course hits are 3341.The number of micro-videos, the number of students and the number of course click are still increasing. By the end of January 2016,the author creates 7 classes in the Moso Teach, a total of 359 students, posting 2262 materials, and carrying out 166 activities.

(3)In the course of the flipped classroom, the author gives priority to the inspiration and question answering, and avoiding the one-sided cramming. The students mainly carry on discussion and cooperative learning, which enhances the ability of their independent study.

Examination reform in the flipped classroom teaching mode. The author takes advantage of the data statistics of Duigoo website and Moso Teach, taking the performance of students in these two platforms into evaluation. The assessment of students' grades in this course, combined with daily evaluation and final evaluation, which includes two aspects, one is the daily performance, which is 100 points, and the students' performance in Duigoo website and Moso Teach accounts for 20\% of the grade; the other is the final examination according to the standards of English course, 100 points, and the oral test, 100 points, accounts for 25\%.That is to say, total mark = daily performance(roly-play, oral and listening 30\% + Duigoo and performance 20\%)50\%+final examination (final oral examination $25 \%$ + final written exam $25 \%$ ) $50 \%$, so as to promote students' effective use of micro-videos or course resources to carry out self-studying. The author uses information technolology to cultivate students' self-studying habits.

\section{Conclusions}

The characteristics and innovations in this thesis are that the author uses micro-videos and in the flipped classroom of College English teaching, cultivating students' self-studying ability, improving teachers' classroom management efficiency and makes specific teaching content and plan, exploring and building a new college English teaching mode, making the College English teaching out of the woods. The author firstly uses Duigoo website and Moso Teach to post micro-videos and materials in the English flipped classroom teaching at home and abroad.

The "flipped classroom" teaching mode breaks the traditional public English teaching mode and examination-oriented mode, enables students to attach more importance to the learning process and English skills, stimulate students' interests in learning English, at the same time promotes students' self-studying ability, and finally improves English teaching quality.

\section{Acknowledgements}

This article is the research result of the following project: Teaching Reform Project of Vocational Education in Shandong Province. Project Number: 2015599

\section{References}

[1] Jonathan Bergmann and Aaron Sams. Flip Your Classroom-Reach Every Student in Every Class Every Day

[2]Things You Should Know About Flipped Classrooms [EB/OL]. [2012-08-20]. http://net.educause.edu/ir/library/pdf/ELI7081.pdf.

[3] CHEN Xiao-fei. Research on the flipped classroom teaching mode [D] Huazhong Normal University master's degree thesis, 2014. 